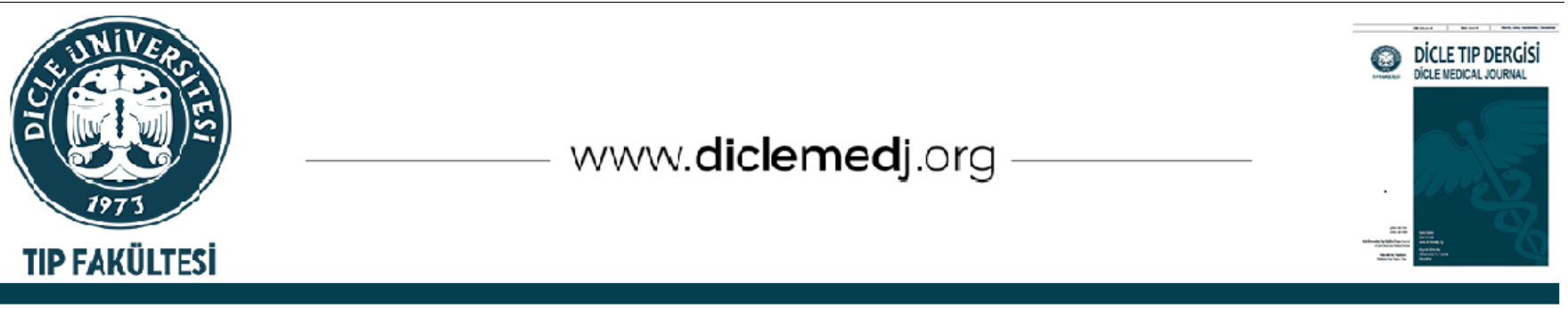

Original Article / Özgün Araştırma

\title{
Pulmonary Aspergillosis in immunocompetent patients
}

\author{
Sibel Kara ${ }^{i}{ }_{1}$, Ebru Oruç ${ }^{i}{ }_{2}$, Zuhal Ekici Ünsal ${ }^{i D_{3}}$, H. Eda Alışkan ${ }^{i}{ }_{4}$, Şule Akçay ${ }_{5}$ \\ 1 Department of Chest Disease, Başkent University Adana Training and Research Center, Adana, Turkey \\ 2 Department of Infectious Diseases and Clinical Microbiology, Başkent University Adana Training and Research Center, Adana, Turkey \\ 3 Department of Chest Disease, Başkent University Adana Training and Research Center, Adana, Turkey \\ 4 Department of Medical Microbiology, Başkent University Adana Training and Research Center, Adana, Turkey \\ 5 Department of Chest Diseases, Başkent University School of Medicine, Ankara, Turkey
}

Received: 24.03.2021; Revised: 11.07.2021; Accepted: 25.07.2021

\begin{abstract}
Objective: Although pulmonary aspergillosis (PA) is often seen in patients with immunodeficiency, it also identifies a number of clinical diseases that cause morbidity and mortality, which can also occur in patients with immunodeficiency. The aim of this study was to investigate the disease patterns, demographic and clinical features, treatment and prognosis of pulmonary aspergillosis in immune competent patients.
\end{abstract}

Method: Our study is a descriptive cross-sectional study in which the data of immunocompetent patients diagnosed with PA in our hospital between January 2010 and Decenber 2019 were evaluated retrospectively. Patients over the age of 18 with a diagnosis of PA were included in the study. Demographic and clinical features, radiological findings, diagnosis and treatment methods and prognoses of the patients were recorded.

Results: 8 of the patients were female, 3 were male and the mean age was 61 (53 \pm 69 ). Nine patients were diagnosed with chronic pulmonary aspergillosis and two patients were diagnosed with IPA. Four of the patient diagnosed with KPA were chronic cavitary pulmonary aspergillosis, one was chronic fibrosing pulmonary aspergillosis, two were aspergilloma and two were aspergillus nodules. The most common comorbidity was diabetes mellitus (45.4\%) and in total, $72.7 \%$ of patients had chronic lung disease such as COPD-asthma, tuberculosis, bronchiectasis. Cough, sputum and hemoptysis $(90 \%, 72.7 \%, 45.4 \%$, respectively) were the most common symptoms. The most common radiological finding on thorax tomography was crescent sign-cavity (72.7\%). The diagnostic method used was mostly bronchoalveolar lavage and wedge resection/ lobectomy (45.4\%, respectively). It was observed that eight (72.7\%) patients were given voriconazole and three (27.2\%) other patients surgical procedure performed and one patient was lost after surgery.

Conclusions: Although pulmonary aspergilosis is more frequently seen in immunocompromised patients with malignancy, solid organ and hematological transplants, it has now begun to be seen in immune competent patients. The majority of our patients were middle-aged, women and smokers, people with comorbidity such as DM and chronic lung disease. Therefore, we would like to point out that pulmonary aspergillosis should be kept in mind among differential diagnoses, especially in patients with immunocompetent with comorbidity such as chronic lung disease and DM.

Keywords: Pulmonary Aspergillosis, immunocompetent patinents, disease patterns, demographic, clinical features, prognosis

DOI: 10.5798/dicletip.987922

Correspondence / Yazışma Adresi: Sibel Kara, Başkent Üniversitesi Adana Dr. Turgut Noyan Uygulama ve Araștırma Merkezi Dadaloğlu, 2591. Sk. No:4 A, 01240 Yüreğir/Adana, Turkey e-mail: sibelkarasb@hotmail.com 


\section{İmmün kompetan Hastalarda Pulmoner Aspergillozis}

Öz

Amaç: Pulmoner aspergillozis (PA) sıklıkla immün yetmezlikli hastalarda görülse de immün kompetan hastalarda da ortaya çıkabilen en önemli morbidite ve mortaliteye neden olan bir dizi klinik hastalığı tanımlar. Amacımız; immün kompetan hastalarda pulmoner aspergillozisin hastalık paternlerini, demografik ve klinik özelliklerini, tedavi yöntemlerini ve prognozunu araştırmaktı.

Yöntemler: Çalışmamız Ocak 2010 ve Aralık 2019 tarihleri arasında hastanemizde PA tanısı alan immün kompetan hasta verilerinin retrospektif olarak değerlendirildiği tanımlayıcı kesitsel bir çalışmadır. 18 yaş üstü PA tanısı alan hastaların demografik verileri, klinik özellikleri, radyolojik bulguları, tanı ve tedavi yöntemleri ile prognozları retrospektif olarak incelendi.

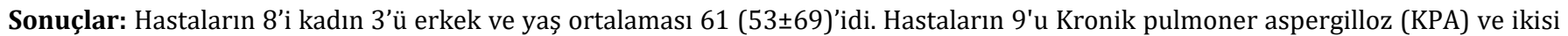
invaziv PA tanısı aldı. KPA tanısı alan hastaların 4'ü kronik kaviter pulmoner aspergilloz, 1'I kronik fibroze pulmoner aspergillozis, 2'si aspergilloma, diğer 2'si aspergillus nodulü idi. En sık saptanan komorbidite diabetes mellitus (\%45,4) olup hastaların \%72,7'sinde koah-astım, tüberküloz, bronşektazi gibi kronik akciğer hastalığı bulunmaktaydı. Öksürük, balgam ve hemoptizi (sırası ile \%90, \%72,7, $\% 45,4)$ en sık görülen semptomlardı. Toraks tomografisinde en sık saptanan radyolojik bulgunun ise hilal belirtisi-kavite (\%72,7) olduğu belirlendi. Uygulanan tanı yöntemleri sıklıkla bronkoalveolar lavaj (BAL) ve wedge rezeksiyon/ lobektomi (sırası ile \%45,4) olarak saptandı. Tedavide sekiz $(\% 72,7)$ hastaya vorikonazol verildiği, diğer üç $(\% 27,2)$ hastaya cerrahi işlem yapıldığı ve bir hastanın ise cerrahi sonrasında kaybedildiği görüldü.

Tartışma: Pulmoner aspergilloz daha sık olarak bağışıklığı zayıflamış kanser, solid organ ve hematolojik nakil hastalarında görülmekle birlikte günümüzde immün kompetan hastalarda da görülmeye başlamıştır. Hastalarımızın çoğunluğunu; orta yaş, kadın, sigara içen, altta yatan DM ve kronik akciğer hastalığı gibi bir komorbiditeye sahip kişiler oluşturmaktadır. Bu nedenle özellikle kronik akciğer hastalığı ve DM gibi altta yatan hastalığı olan immün kompetan hastalarda hastalarda pulmoner aspergillozun ayırıcı tanılar arasında akılda tutulması gerektiğine dikkat çekmek istiyoruz.

Anahtar kelimeler: Pulmoner aspergillozis, immun kompetan hasta, hastalık paternleri, demografik, klinik özellikler, prognoz.

\section{INTRODUCTION}

Aspergillus spp. It is a widely isolated fungus species both in the external environment (soil, plant residues) and in many indoor environments including hospitals ${ }^{1}$. Aspergillus causes various clinical syndromes. Host immunity is of great importance in the symptoms, clinical course and disease severity of aspergillus infections. The interaction between the pathogen and host immune dysfunction or hyperactivity determines which clinical syndrome is more likely to develop. Nowadays, invasive aspergillosis (IA) can often be seen in immunocompromised neutropenic patients as well as increasingly in nonneutropenic hosts (such as organ transplant patients, critically ill patients, and patients receiving steroids). Görük et al. reported that IA developed in $15 \%$ of febrile neupenic patients with hematological malignancies ${ }^{2}$. IA can be seen in immunocompetent hosts that a re heavily exposed to fungal spores ${ }^{3}$. Chronic pulmonary aspergillosis (CPA) is a type of disease that causes severe lung damage and is mostly seen in patients with mild immunodeficiency or an underlying lung chronic lung disease (COPD, previous or concurrent tuberculosis (TB) or non-TB mycobacterial disease) ${ }^{4}$.

\section{METHOD}

This is a descriptive cross-sectional study in which the data of immunocompetent patients diagnosed with pulmonary aspergillosis in our hospital between January 2010 and December 2019 were evaluated retrospectively. Our aim was to determine the disease patterns, demographic and clinical features, and prognosis of pulmonary aspergillosis in immunocompetent patients. Patients over the age of 18 with a diagnosis of PA were included in the study. Data of patients were obtained from their electronic files. Demographic, clinical, radiological features, comorbidities, diagnosis and treatment methods of the patients were recorded. Ethics committee 
approval was obtained for our study with the date of 06.10 .2020 and no KA 20/368.

\section{Study population and case definitions}

Pulmonary aspergillosis diagnosis was established according to diagnostic criteria of international guidelines: The diagnosis of "proven IPA (invasive pulmonary aspergillosis)" was made by demonstrating hiphya compatible with aspergillus in samples taken by lung biopsy or needle aspiration and/ or identify of any upper and lower respiratory secretion from the culture.

We did not have any patients meeting the criteria of "possible IPA" and "possible IPA" 2 .

CPA; mostly consists of a series of disease patents seen in patients with underlying lung disease (3). These clinical conditions are defined as chronic cavitary pulmonary aspergillosis (CCPA) - untreated and if progress occurs CFAP (chronic fibrous pulmonary aspergillosis), aspergilloma, Aspergillus nodules (AN). The diagnosis of CPA was established according to the following criteria of The European Society for Clinical Microbiology and Infectious Diseases (ESCMID), the European Respiratory Society (ERS) and the European Confederation of Medical Mycology (ECMM) 2017: (i) one or more nodules with or without fungal ball on thorax CT ii) direct exclusion of Aspergillus spp by biopsy culture or microscopy or exclusion of an immunological response to Aspergillus spp (iii) all present for at least 3 months ${ }^{6,7}$.

In CCPA; there are one or several thick-walled cavities (when dense fungus hyphae intertwine with collections) with or without fungus balls that develop in a few months ${ }^{8}$. If CCPA is left untreated, it can progress, and intense fibrotic destruction occurs in lung tissue. This condition is classified as chronic fibrosing pulmonary aspergillosis (CFPA) leading to respiratory failure ${ }^{9}$. Aspergilloma is a fungus ball composed of aspergillus hyphae, fibrin, mucus, inflammatory cells degenerate blood and epithelial elements in the pre-existing cavity ${ }^{10}$. Aspergillus nodules are generally defined as solid nodules detected incidentally on CT, which may be single or multiple, especially those that can be confused with conditions such as lung cancer ${ }^{11}$.

\section{Study case exclusion criteria}

1- Aspergillus spp. colonization (without aspergillus infection) 2-Severe immunosuppressive patients with solid organ transplantation, hematopoietic stem cell transplantation and receiving chemotherapy for malignancy. 3-In addition, we did not have any patients with allergic bronchopulmonary aspergillosis (ABPA) with follow-up during the screening period for the study.

The antifungal treatment response of our patients was evaluated according to the criteria in the ESCMID / ECMM / ERS clinical guidelines ${ }^{6,7}$.

\section{Microbiological processes}

All upper and lower respiratory tract samples were cultured in sabouraud dextrose agar with and without antibiotics after direct microscopic examination. These were incubated in incubators at $25^{\circ} \mathrm{C}$ and $37^{\circ} \mathrm{C}$ for 3 weeks. Identification of a colony with mold growth was carried out at species level according to macroscopic and microscopic morphology ${ }^{12}$. Serum galactomannan (GM) antigen level was determined with Platelia Aspergillus Galactomannan EIA kits. For GM, a rate $0.5 \mathrm{ng} / \mathrm{mL}$ was considered positive ${ }^{13}$.

\section{Statistical Analysis}

Statistical analysis of the data was done using SPSS 25.0 package program. Categorical measurements were summarized as number and percentage, whereas continuous measurements were summarized as mean and standard deviation (median and minimum-maximum, where necessary). 
Table I: Diagnostic criteria for invasive fungal disease

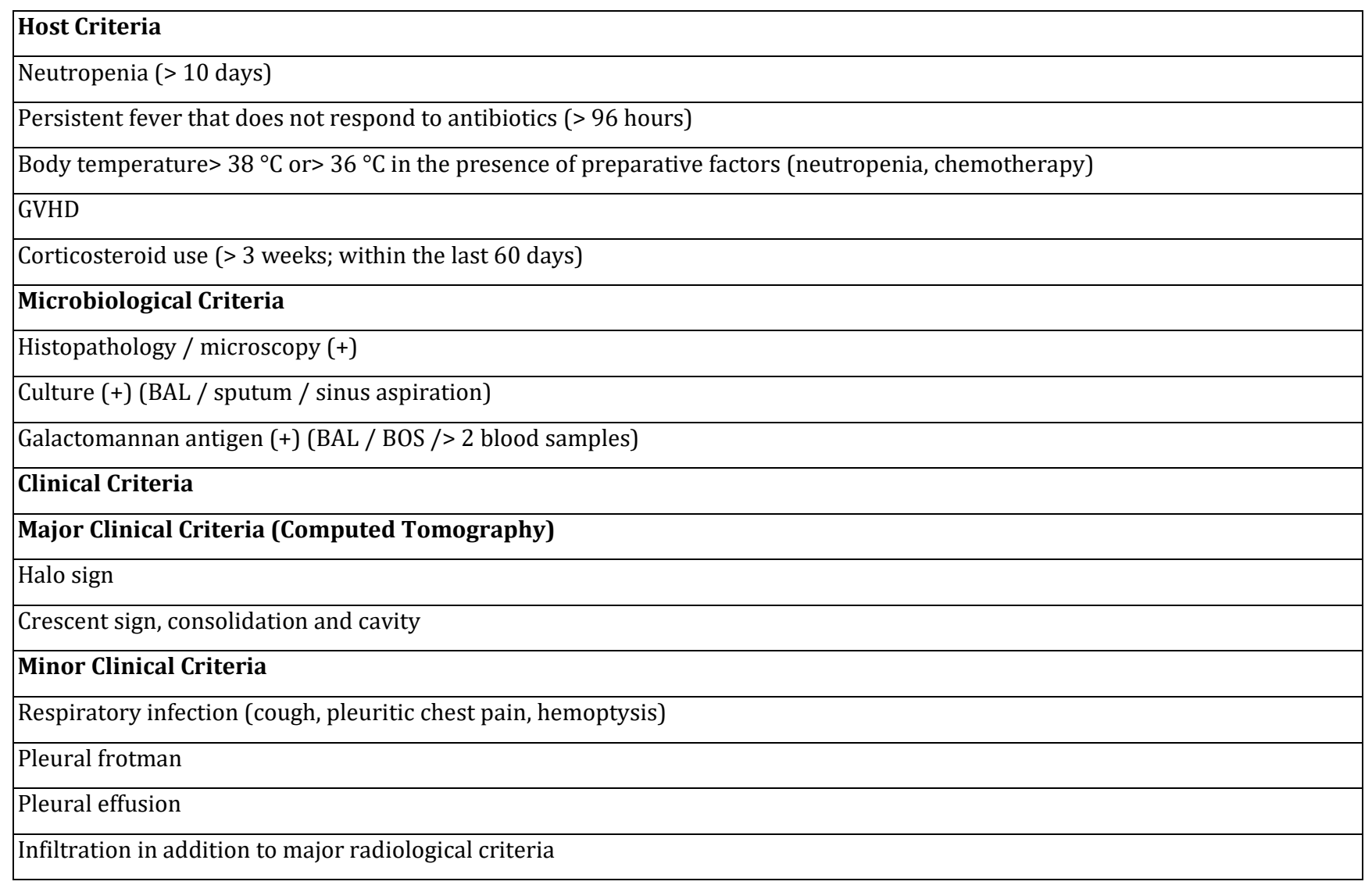

GCVD: Graft versus host disease, BAL: Bronchoalveolar lavaj

Table II: IPA (Invasive pulmonary aspergillosis) diagnose

\section{Proven IPA}

Histopathology / cytopathology (+) \{culture\} Example: Biopsy / needle aspiration

Culture (+) Example: Sterile body area (excluding urine and mucosa)

\section{Strongly Probable IPA}

$>1$ host +1 microbiological criterion +1 major (or 2 minor) clinical criterion

Possible IPA

$>1$ host criterion +1 microbiological or 1 major (or 2 minor) clinical criterion

A total of 11 patients: 9 (81.1\%) were diagnosed with CPA [4 (56. 3\%) CCPA, 1 (9.1\%) CFPA 2 (18.1\%) aspergilloma, 2 (18.1\%) aspergillus nodule] and the other 2 (18.1\%) were diagnosed as IPA. Eight (72.7\%) were female, 3 $(27.3 \%)$ were male and the mean age was 61 (53-69). Eight patients (72.7\%) were smoker. The most common comorbidity was DM 5 (45.4\%) patients, and it was also found in 8
(72.7\%) patients in total $(27.2 \%, 27.2 \%$, $18.1 \%)$, respectively, with choronic respiratory disease. Cough $10(90 \%)$ and sputum 8 (72.7\%) were the most common symptoms. Hemoptysis was also remarkably 5 (45.4\%). Three patients with malignancy (skin-basal cell carcinoma, thyroid follicular carcinoma) did not receive chemotherapy. 
Table III: Patient diagnoses, demographic and clinical features

\begin{tabular}{|c|c|}
\hline \multicolumn{2}{|c|}{ N: $11(\%)$} \\
\hline Patient diagnoses & \\
\hline KPA & $9(81.1)$ \\
\hline KKРA & \\
\hline KFPA & $4(36.3)$ \\
\hline & $1(9.1)$ \\
\hline Aspergilloma & $2(18.1)$ \\
\hline Asperllus nodule (AN) & $2(18.1)$ \\
\hline İPA & $2(18.1)$ \\
\hline Gender M / F & $8(72.7) / 3(27.3)$ \\
\hline Mean age & $61(53 \pm 69)$ \\
\hline Smoker & $8(72.7)$ \\
\hline Ex-smoker & $1(9.1)$ \\
\hline Non-smoker & $2(18.1)$ \\
\hline \multicolumn{2}{|l|}{ Comorbidity } \\
\hline Diabetes Mellitus & $5(45.4)$ \\
\hline COPD / Asthma & $3(27.2)$ \\
\hline Lung tuberculosis & $3(27.2)$ \\
\hline Bronchiectasis & $2(18.1)$ \\
\hline $\begin{array}{l}\text { Malignancy (skin-basal cell ca / } \\
\text { thyroid follicular ca) }\end{array}$ & $3(27.2)$ \\
\hline Hypertension & $2(18.1)$ \\
\hline Coronary artery disease & $2(18.1)$ \\
\hline Romatoid artrit & $1(9.1)$ \\
\hline Chronic renal failure & $1(9.1)$ \\
\hline \multicolumn{2}{|l|}{ Clinical symptoms } \\
\hline \begin{tabular}{|l|} 
Cough \\
\end{tabular} & $10(90.9)$ \\
\hline Sputum & $8(72.7)$ \\
\hline Hemoptysis & $5(45.4)$ \\
\hline Pleuretic chest pain & $3(27.2)$ \\
\hline Fever & $1(9.1)$ \\
\hline
\end{tabular}

Table IV: Patient thorax computed tomography (CT) findings, diagnosis and treatment method

\begin{tabular}{|lc|}
\hline Thorax CT Findings & N : 11 (\%) \\
\hline Crescent sign, cavity & $2(72.7)$ \\
\hline One-sided nodule & $1(9.1)$ \\
\hline Bilateral nodules & - \\
\hline Halo sign & $5(45.4)$ \\
\hline Diagnostic Method & $5(45.4)$ \\
\hline BAL (Bronchoalveolar lavage) & $1(9.1)$ \\
\hline Wegde resection & $1(9.09)$ \\
\hline Bronchial biopsy & \\
\hline Transthoracic biopsy & $8(72.7)$ \\
\hline Treatment Method & $3(27.2)$ \\
\hline Voricanaozole & $6(63.6)$ \\
\hline Surgical treatment & $2(18.2)$ \\
\hline Antifungal therapy & $1(9.1)$ \\
\hline 12 weeks & \\
\hline 8 weeks & \\
\hline Mortality & \\
\hline$N:$ Number patients & \\
\hline
\end{tabular}

Radiological findings, diagnosis and treatment methods of the patients are shown in Table IV.It was found that the disease was most commonly seen in thorax CT in 8 (72.7\%) patients as crescent-cavity and $2(18.2 \%)$ in the form of nodules. The diagnosis was most commonly made with bronchoalveolar lavage (BAL) in 5 (45.4\%) patients, wedge resection / lobectomy in $5(45.4 \%)$ and transthoracic needle biopsy in another patient. It was found that 8 (72.7\%) patients had voriconazole as an antifungal drug and $3(27.2 \%)$ patients underwent surgery. During follow-up, one (9.1\%) patient was found to be lost.

Thorax CT images of the patients with pulmonary aspergillosis according to the disease type are shown in Table V. 
Table V: Thorax CT images of the patients with pulmonary aspergillosis according to the disease type

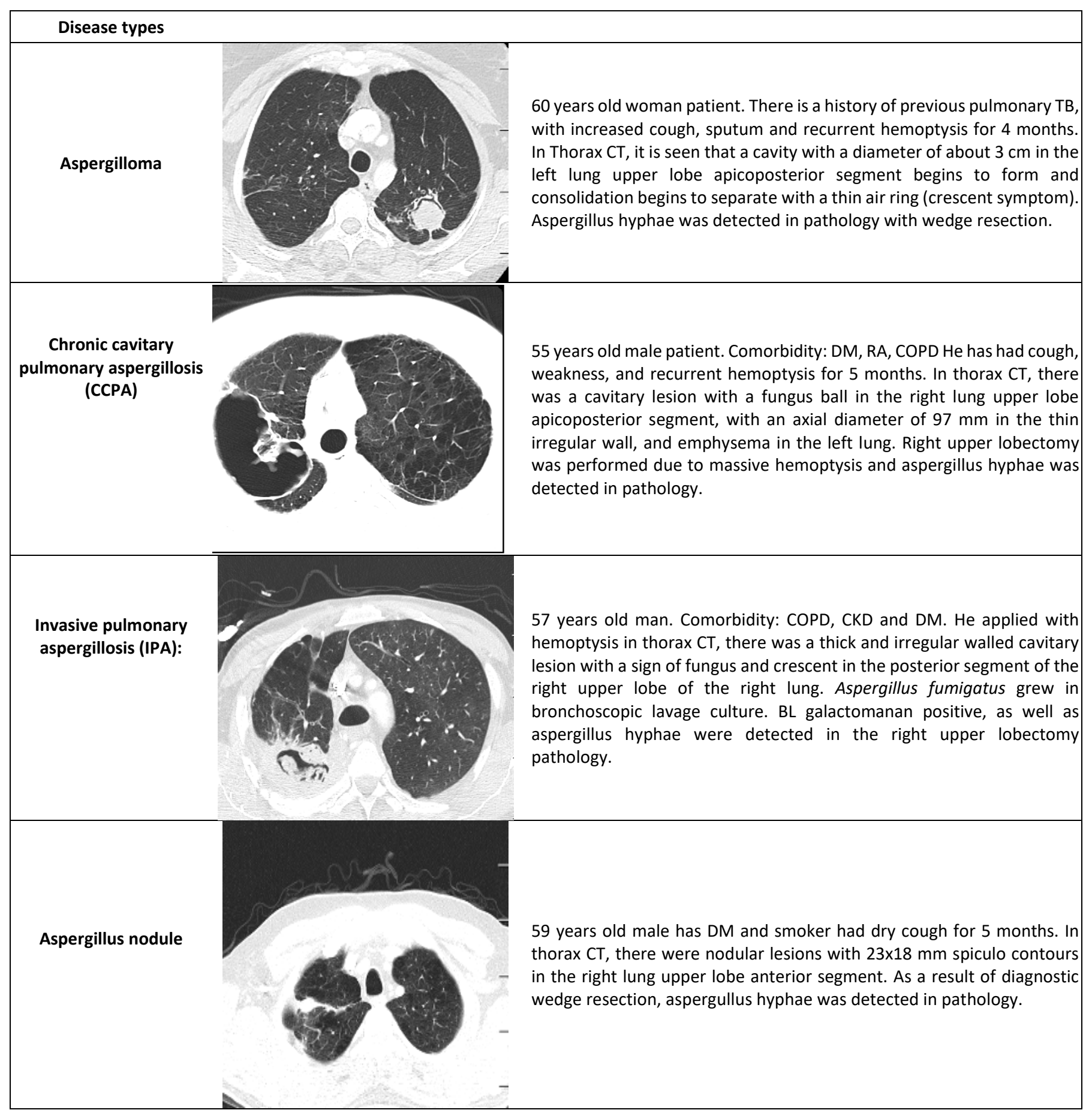

\section{DISCUSSION}

In this study, diagnosed patients with immunocompetent pulmonary aspergillosis were analyzed. All of the 11 patients 9 were KPA
(4 KKPA, 1 KFPA. 2 aspergilloma, 2 aspergillus nodules) and the other 2 patients were IPA.

CPA is a neglected pulmonary fungal infection that is estimated to affect more than 3 million people worldwide ${ }^{14,15}$. It has been found that 
patients with CPA are generally middle-aged and male3. Our patient group was middle-aged (mean age 61 ), but $82.7 \%$ were women. The high female gender may be related to the single center and patient population of our study.

CCPA is the most common form of CPA, these cavities expand over time ${ }^{8}$. In our study also the most common diagnosis was CCPA (36.3\%) and cavities had large diameters. In our study, which was compatible with the literature, the most common diagnosis was KKPA (36.3\%). The main risk factors are underlying diseases, especially causing structural damage to the lung; TB, non-TB mycobacteria (NTM) lung diseases, chronic obstructive pulmonary disease (COPD), emphysema, bronchiectasis, asthma, pneumothorax, sarcodosis, pneumonia and other chronic pulmonary diseases ${ }^{16,17}$. Smith et al. revealed that comorbidity was the most common in tuberculosis and other common conditions in COPD and emphysema in 126 non-immunocompromised patients ${ }^{4}$. As in the literature, it was determined that most of our patients had chronic lung diseases such as tuberculosis, COPD, asthma and bronchiectasis. In addition, $81.1 \%$ of patients smoked. Smoking rate of women is high in our country $(13.3 \%)^{18}$. This may have contributed to the formation of chronic lung diseases in patients.

In previous years, it has been shown that the necrotic form of KPA may also occur in patients with mild immune deficiency due to connective tissue diseases such as DM, alcoholism, chronic liver and kidney disease, corticosteroid therapy, malnutrition or rheumatoid arthritis ${ }^{19}$. In our study, the most common comorbidity in accordance with the literature was DM. In addition, these patients had other comorbidities such as chronic renal failure and COPD. We think that these underlying diseases may have contributed to the emergence of a fungal infection such as pulmonary aspergillosis by adversely affecting the immune system and defense mechanisms of the host.
Aspergillus and aspergillosis nodules are less severe forms of CPA. Aspergillus is a fungal ball that commonly occurs in the TB cavity, the underlying cavitary disease ${ }^{10}$. In a study evaluating 544 patients with post-tuberculosis cavity, $11 \%$ had radiological findings of aspergilloma ${ }^{20}$. Two of our 3 patients who were diagnosed with aspergilloma had a history of previous tuberculosis.

It is known that IPA is also seen in nonneutropenic immunocompetent patients without classical risk factors ${ }^{3}$. Patients with severe COPD and critically ill patients have the highest risk in this group. There are several reasons for increasing sensitivity to IPA in COPD patients. These; changes in the lung structure, long-term use of corticosteroid therapy, frequent hospitalizations, antibiotic therapy, invasive applications, impaired mucociliary clearance and accompanying comorbid diseases such as diabetes mellitus and malnutrition ${ }^{21}$. In a multicenter study excluding patients with classic risk factors from the USA, $77 \%$ of critically ill patients with IA (invasive aspergillus) were found to have taken high-dose steroids during their hospitalization ${ }^{22}$. Both of our patients with IPA had severe COPD, DM, frequent hospital admissions, and long-term use of high doses of steroid.

Symptoms of CPA are nonspecific so diagnosis may be delayed. The most common symptom of the disease is productive cough; others are weight loss and dyspnea ${ }^{23}$. It has been shown that hemoptysis frequently occurs in patients with aspergilloma and can be life-threatening 24 . The most common symptoms consistent with the literature in our patients was cough, sputum and hemoptysis.

CPA appears with radiographic findings such as crescent sign- cavitation (with or without a fungus ball) pleural thickening, peri cavitary infiltrates in thorax $\mathrm{CT}^{25}$. Typical finding for CCPA is consolidation in the upper lobes that 
progresses to cavitation over time and causes volume loss8. Simple aspergilloma occurs as a solid opacity in the upper lobe or as a cavitycreating appearance when the mass separates from the wall in the cavity ${ }^{26,27}$. In our patients, the most common radiological finding in thorax CT was crescent sign-cavity (72.7\%).

Diagnosis for CPA: clinical, radiological findings and compliance with diagnostic criteria such as demonstrating aspergillus infection (tissue biopsy and / or microbiological culture) 6-25 Diagnosis of IPA is also quite difficult in the patient group without typical risk factors. The gold standard for diagnosis is biopsy of lung tissue and / or culture of positive Aspergillus spp. Infection has been proven in half of our patients with reproduction in BAL culture and in the other half by wedge resection / lobectomy and pathological aspergillus hyphae. The reason for the frequent use of surgery in diagnosis is that this method was used for diagnosis and treatment because almost half of our patients applied with serious hemoptysis.

The goal of treatment in CPA is to improve symptoms, reduce and / or prevent hemoptysis and lung fibrosis. Voriconazole or itraconazole is recommended as the first-line treatment option $^{28}$. Voriconoazole is primarily recommended in IPA because it decreases mortality. The recommended duration of treatment is 12 weeks, depending on the clinical response, longer treatment may be required ${ }^{7}$. $72.7 \%$ of our patients received voriconazole treatment for 12 weeks.

Even when CPA is treated, a 5-year mortality is around $20-50 \%{ }^{29}$. Hemoptysis is a complication that can be fatal in patients with CPA. Surgery may be considered in severe hemoptysis or treatment failure, but the rate of postoperative complications is high30. In our study, 3 (27.2\%) patients with moderate and severe hemoptysis were operated for diagnosis and treatment, and only one was lost postoperatively. Our other

patients improved clinically and radiologically. Our results were determined in accordance with the studies in the literature ${ }^{29,30}$.

Our study has some limitations. The study was single-centered, so the number of patients is relatively small and does not represent the general population. In addition, the reason why our study is a retrospective study was made according to the diagnostic criteria of international guidelines using the examinations performed on the patients. Our number of patients may be low due to the lack of appropriate diagnostic methods. When pa related literature was reviewed from our country, it was published in the form of case reports. Our study has the highest number of patients from our country, and we think it will contribute to the literature. There is a need to plan forward-looking, multicenter studies.

As a result, in this study; we have revealed the clinical patterns of pulmonary aspergillosis in immune composite patients. The majority of patients are middle-aged, female and smokers. The most common symptoms were productive cough and hemoptysis. All patients had comorbidities most frequently, such as DM and underlying chronic lung disease. The prognosis was quite good. We think that pulmonary aspergillosis, which we know to be seen in people who suppress the immune system, should be kept in mind among the options of diagnosis in immune competent individuals.

Ethics Committee Approval: Ethics committee approval was obtained for our study with the date of 06.10.2020 and no KA 20/368.

Declaration of Conflicting Interests: The authors declare that they have no conflict of interest.

Financial Disclosure: No financial support was received. 


\section{REFERENCE}

1. Soubani AO, Chandrasekar PH. The clinical spectrum of pulmonary aspergillosis. Chest. 2002; 121: 1988-99.

2. Görük M, Dal MS, Dal T, et al. Evaluation of febrile neutropenic patients hospitalized in a hematology clinic. Asian Pacific Journal of Tropical Biomedicine. 2015; 5: 1051-4.

3. Kosmidis C, Dening DW. The clinical spectrum of pulmonary aspergillosis. Review: Thorax. 2015; 70: 270-7.

4. Smith NL, Denning DW. Underlying conditions in chronic pulmonary aspergillosis including simple aspergilloma. Eur Respir J. 2011; 37: 865-72

5. Donnelly JP, Chen SC, Kauffman CA, et al. Revision and update of the consensus definitions of invasive fungal disease from the european organization for research and treatment of cancer and the mycoses study group education and research consortium. Clin Infect Dis. 2020; 71: 1367-76.

6. Salzer HJ, Heyckendorf J, Kalsdorf B, et al. Characterization of patients with chronic pulmonary aspergillosis according to the new ESCMID/ERS/ECMM and IDSA guidelines. Mycoses. 2017; 60: 136-42.

7. Ullmann AJ, Aguado JM, Arikan-Akdagli S, et al. Diagnosis and management of Aspergillus diseases: executive summary of the 2017 ESCMID-ECMM-ERS guideline. Clin Microbiol Infect. 2018; 2: 1-38.

8. Denning DW, Cadranel J, Beigelman-Aubry C, et al. Chronic pulmonary aspergillosis: rationale and clinical guidelines for diagnosis and management. Eur Respir J. 2016; 47: 45- 68.

9. Kosmidis C, Newton P, Muldoon EG \& Denning DW. Chronic fibrosing pulmonary aspergillosis: a cause of 'destroyed lung' syndrome. Infect Dis. 2017; 49: 296-301.

10. Chamilos G, Kontoyiannis DP. Aspergillus, candida, and other opportunistic mold infections of the lung. Fishman's pulmonary diseases and disorders. 5th edition. McGraw-Hill Education, New York 2015.
11. Muldoon EG, Sharman A, Page I et al. Aspergillus nodules; another presentation of chronic pulmonary aspergillosis. BMC Pulm Med. 2016; 16: 123.

12. Verweij PE, Brandt ME: Aspergillus, Fusarium, and other opportunistic moniliaceous fungi. Manual of Clinical Microbiology, 9th edition. Washington: ASM Press; 2007:1802-38.

13. Marchetti 0 , Lamoth F, Mikulska $M$, et al., European Conference on Infections in Leukemia (ECIL) Laboratory Working Groups: ECIL recommendations for the use of biological markers for the diagnosis of invasive fungal diseases. Bone Marrow Transplant. 2012; 47: 846-54.

14. Denning DW, Pleuvry A, Cole DC. Global burden of chronic pulmonary aspergillosis complicating sarcoidosis. Eur Respir J. 2013; 41: 621-6.

15. Global Action Fund for Fungal Infections. Fungal Disease http://www.gaffi.org/why/fungal-diseasefrequency/. 2016.

16. Camara B, Reymond E, Saint-Raymond C, et al. Characteristics and outcomes of chronic pulmonary aspergillosis: a retrospective analysis of a tertiary hospital registry. Clin Respir J. 2015; 9: 65-73.

17. Takeda K, Imamura $Y$, Takazono $T$, et al. The risk factors for developing of chronic pulmonary aspergillosis in nontuberculous mycobacteria patients and clinical characteristics and outcomes in chronic pulmonary aspergillosis patients coinfected with nontuberculous mycobacteria. Med Mycol. 2016; 54: 120-7.

18. Türkiye İstatistik Kurumu Başkanlığı (TÜİK), Küresel yetişkin tütün araştırması, 2012, http://www.tuik.gov.tr/PreHaberBultenleri.do?id= 13142

19. Binder RE, Faling LJ, Pugatch RD, et al. Chronic necrotizing pulmonary aspergillosis: a discrete clinical entity. Medicine (Baltimore). 1982; 61: 10924.

20. Aspergilloma and residual tuberculous cavities the results of a resurvey. Tubercle 1970; 51: 227-45.

21. Lionakis MS, Kontoyiannis DP. Glucocorticoids and invasive fungal infections. Lancet. 2003; 362: 1828-38. 
22. Baddley JW, Stephens JM, Ji X, et al. Aspergillosis in Intensive Care Unit (ICU) patients: epidemiology and economic outcomes. BMC Infect Dis. 2013; 13: 29.

23. Schweer KE, Bangard C, Hekmat K \& Cornely OA. Chronic pulmonary aspergillosis. Mycoses. 2014; 57: 257-70.

24. Gao Y, Soubani A. Advances in the diagnosis and management of pulmonary aspergillosis. Adv Respir Med. 2019; 87: 231-43.

25. Patterson TF, Thompson GR, Denning DW, et al. Practice guidelines for the diagnosis and management of aspergillosis: 2016 update by the infectious diseases society of America. Clin Infect Dis. 2016; 63: 1-60.

26. Franquet T, Müller N, Giménez A, et al. Spectrum of pulmonary aspergillosis: histologic, clinical, and radiologic fndings. RadioGraphics. 2001; 21: 82537.

27. Davda S, Kowa XY, Aziz Z, et al. The development of pulmonary aspergillosis and its histologic, clinical, and radiologic manifestations. Clin Radiol. 2018; 73: 913-21.

28. Tashiro M, Takazono T, Saijo T, et al. Selection of oral anti- fungals for initial maintenance therapy in chronic pulmonary aspergillosis: A longitudinal analysis. Clin Infect Dis. 2020; 70: 835-42

29. Nam HS, Jeon $K$, Um SW, et al. Clinical characteristics and treatment outcomes of chronic necrotizing pulmonary aspergillosis: a review of 43 cases. Int J Infect Dis. 2010; 14: 479-82.

30. He B, Wan C, Zhou W. Clinical profile and surgical outcome for different types of chronic pulmonary aspergillosis. Am J Transl Res. 2019; 11: 3671-9. 